\title{
PROFIL PERILAKU MASYARAKAT TENTANG PERSIAPAN OBAT DAN PENCARIAN INFORMASI TEMPAT TUJUAN SEBELUM BEPERGIAN
}

\author{
Elida Zairina*, Noor Annisa Mones, Nadhifah Dhia Zahrah, Firdausa Rahmah, Naufal Hafizalwan, Lilla \\ Sapta Ratri, Fitri Amalia Siswanto, Diyna Rusayliya Purwanto, Yusuf Alif Pratama, Yuhan Adelina \\ Wihda Fikriyah, Balqis Sofea Binti Borhan
}

Departemen Farmasi Komunitas, Fakultas Farmasi, Universitas Airlangga Gedung Nanizar Zaman Joenoes Kampus C, J1. Ir. Soekarno, Surabaya 60115, Indonesia

E-mail: elida-z@ff.unair.ac.id

\begin{abstract}
ABSTRAK
Pada era globalisasi, banyak orang bepergian dengan berbagai keperluan, terutama perjalanan liburan. Peningkatan jumlah perjalanan memicu banyaknya orang yang bepergian terkena penyakit selama atau setelah melakukan perjalanan. Hal ini disebabkan orang-orang tersebut kurang memiliki pengetahuan tentang pre-travel health preparation. Untuk mengetahui tingkat kesiapan masyarakat terkait kesehatan sebelum bepergian, dilakukan survei di Terminal Bus Bungurasih, Sidoarjo pada bulan September 2019. Penelitian ini didesain secara cross-sectional dengan 150 responden. Pengambilan data dilakukan secara accidental sampling dengan instrumen kuesioner. Dari data survei, diperoleh hasil sebesar 56,7\% responden melakukan pencarian informasi terkait tempat tujuan dimana jumlah laki-laki (n=49) lebih banyak daripada perempuan $(\mathrm{n}=36)$. Jenis informasi yang dicari responden terkait tempat tujuan paling banyak adalah perihal transportasi $(47,3 \%)$. Responden yang tidak mencari informasi mengenai tujuan perjalanan $(38,7 \%)$ umumnya merasa sudah memiliki persiapan yang cukup. Obat pribadi yang paling banyak dibawa pada saat perjalanan adalah minyak kayu putih $(n=39)$ dan sebanyak 46 dari 69 responden mengalami gangguan kesehatan selama perjalanan berupa pusing. Dari hasil survei dapat disimpulkan bahwa perbekalan selama perjalanan terkait dengan obat-obatan tiap individu berbeda tergantung dari tujuan perjalanan. Selain itu, beberapa wisatawan membutuhkan waktu persiapan lebih lama tergantung dari jarak dan tujuan perjalanan.
\end{abstract}

Kata Kunci: Obat, pengetahuan, persiapan kesehatan pra-perjalanan, informasi perjalanan

\section{ABSTRACT}

In the globalization era, many people travel with various purposes, especially holiday travel. The increasing number of travels trigger travelers' health problems during or after traveling. This is due to travelers having less knowledge about pre-travel health preparation. To find out level of community preparedness regarding health preparation before traveling, a survey was conducted at the Bungurasih Bus Terminal, Sidoarjo in September 2019. This study was cross-sectional study with 150 respondents. Data were collected by accidental sampling using a questionnaire. The results show that about $56.7 \%$ of respondents conducted an information search related to destination which more men $(n=49)$ did than women $(\mathrm{n}=36)$. Transportation was the most information sought by respondents regarding destination (47.3\%). The most respondents' reason did not seek information about travel destination was they already had sufficient preparation $(38.7 \%)$. The most personal medication taken during travel was eucalyptus oil $(n=39)$ and 46 of 69 respondents had headache. The survey summarized that drug supplies during travels was different individually, according to the purpose of the travel. Some travelers need more time preparation depends on the length of travel and their destination.

Keywords: drug, knowledge, pre-travel health preparation, travel information 


\section{PENDAHULUAN}

Pada era globalisasi banyak orang bepergian dengan berbagai keperluan, seperti bisnis, liburan, pendidikan, ataupun sebagai relawan kegiatan kemanusiaan. Seiring dengan berkembangnya sistem ekonomi komersial, semakin banyak orang yang berminat melakukan perjalanan yang mengakibatkan jumlah wisatawan dan turis internasional meningkat setiap tahunnya. Berdasarkan Badan Pusat Statistik, terdapat peningkatan jumlah kunjungan wisatawan mancanegara di Indonesia sebesar 12,58\% pada tahun 2018. Sementara, jumlah wisatawan tahunan diperkirakan mencapai hampir dua miliar secara global pada tahun 2030 (Turkish Statistical Institute, 2017).

Perjalanan wisata yang semakin
meningkat jumlahnya telah timbulnya permasalahan baru di bidang kesehatan, yaitu banyaknya wisatawan yang terkena penyakit selama atau setelah melakukan perjalanan. Sebanyak $15 \%$ wisatawan berisiko terjangkit infeksi selama perjalanan. Akan tetapi, kemungkinan terjadinya penyakit serius atau kematian pada wisatawan sangat kecil. Sebuah penelitian tentang masalah kesehatan wisatawan selama tinggal di negara berkembang menunjukkan bahwa diare merupakan penyakit dengan persentase terbesar yaitu 20-60\%. Meskipun tingkat kematiannya rendah, insiden penyakit menular sangat tinggi diantara wisatawan (Kamata et al., 2017).

$$
\text { Berdasarkan penelitian yang }
$$

dilakukan Poksiri et al., (2018) menunjukkan bahwa sebagian besar wisatawan tidak mengetahui risiko kesehatan dan tidak mengambil tindakan pencegahan atau mencari informasi kesehatan sebelum bepergian. Pencarian informasi tersebut dapat membantu wisatawan terhindar dari risiko terkena berbagai penyakit. Beberapa wisatawan tidak mencari informasi terkait daerah yang akan dikunjungi, seperti cuaca, pola hidup, akomodasi, transportasi, tingkat kriminalitas, dan informasi mengenai kesehatan, seperti sarana prasarana kesehatan, risiko terkena penyakit selama perjalanan, dan kemudahan akses untuk mendapatkan obat.

Penelitian lain yang dilakukan di agen perjalanan di Kota Caserta dan Naples, Italia pada Mei-September 2018 menyatakan bahwa sebanyak $25,6 \%$ partisipan memiliki pengetahuan yang kurang tentang penyakit menular pada tempat yang akan dikunjungi. Sementara, 91\% dari seluruh partisipan tidak peduli tentang risiko terkena penyakit menular selama bepergian. Penelitian ini membuktikan tentang pentingnya peran tenaga kesehatan untuk mengedukasi dan menambah pengetahuan wisatawan terkait penyakit yang terjadi selama bepergian serta cara pencegahannya (Adou et al., 2019).

Apotek merupakan salah satu fasilitas pelayanan kesehatan yang mudah diakses dengan jam praktik yang lebih lama. Hal tersebut memudahkan pasien bertemu dengan apoteker untuk mendapatkan konseling mengenai obat dengan resep, seperti obat antimalaria, maupun obat tanpa resep seperti, antidiare, lotion antiserangga, dan tabir surya untuk keperluan perjalanan. Konseling sebelum perjalanan pada umumnya bertujuan untuk pencegahan penyakit dan cedera, sehingga keterampilan diagnostik seringkali tidak diperlukan. Oleh karena itu, keahlian apoteker dalam terapi obat dan kemudahan penjangkauan menciptakan peluang bagi apoteker untuk meningkatkan jumlah dan kualitas konsultasi pra-perjalanan yang diterima oleh wisatawan (Houle, 2018). Maka dari itu, perlu dilakukan penelitian untuk mengetahui profil perilaku masyarakat tentang persiapan obat dan pencarian informasi tempat tujuan sebelum bepergian. Selanjutnya, profil profil tersebut dapat digunakan untuk mengetahui pentingnya melakukan promosi kesehatan tentang Pre-Travel Health Preparation oleh apoteker.

\section{METODE PENELITIAN}

Penelitian ini didesain secara crosssectional dan dilakukan pengambilan data secara accidental sampling mengacu pada penelitian Chalidi (2017) dengan menggunakan kuesioner. Sifat pertanyaan dalam kuesioner ini adalah kombinasi terbuka dan tertutup yang berisi pertanyaan tentang perjalanan dan rencana bepergian responden, berjumlah 12 pertanyaan. Pengumpulan data dilakukan pada hari Sabtu-Senin, 7-9 September 2019 dengan cara meminta responden yang ditemui di Terminal Bungurasih, Sidoarjo untuk mengisi kuisioner. Kriteria responden yang diinginkan adalah masyarakat yang akan melakukan perjalanan, sedang menunggu kedatangan bus dan bersedia untuk berpartisipasi dalam survei ini.

\section{HASIL DAN PEMBAHASAN}

Berdasarkan survei yang telah dilakukan, 29 dari 179 orang tidak bersedia 
untuk berpartisipasi menjadi responden. Ketidaksediaan tersebut dikarenakan berbagai alasan seperti, bus keberangkatan telah tiba, menunggu jemputan pulang, hanya mengantar orang, tidak ingin diganggu, dan tidak bisa membaca. Sehingga didapatkan 150 orang yang bersedia menjadi responden pada penelitian ini (Gambar 1).

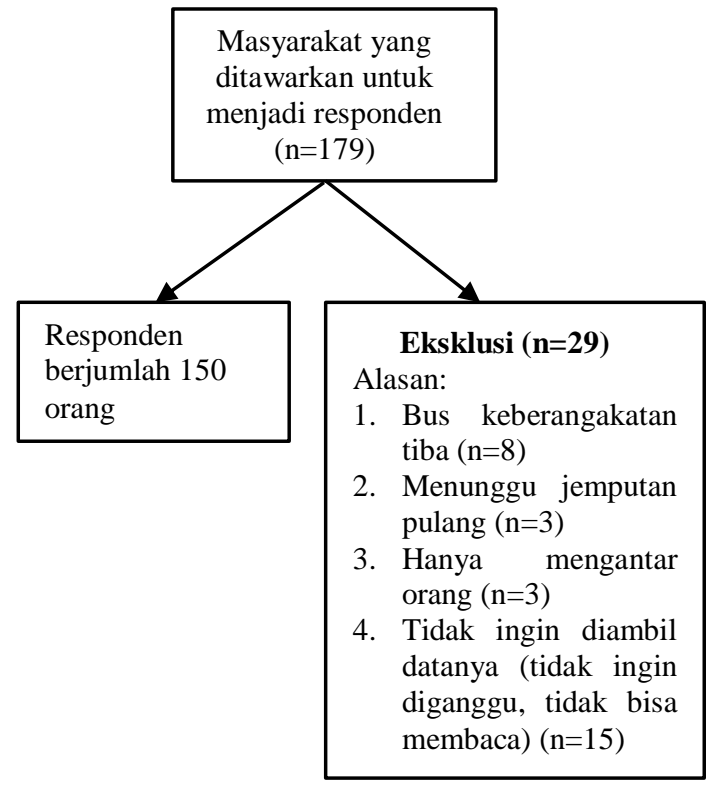

Gambar 1. Flowchart Responden

Tabel 1 menampilkan data demografi dari 150 responden dengan jenis kelamin laki-laki sebanyak 89 orang $(59,3 \%)$ dan perempuan sebanyak 61 orang $(40,7 \%)$. Berdasarkan responden tersebut, perempuan $(59,0 \%)$ lebih banyak mencari informasi persiapan sebelum bepergian daripada lakilaki $(55,1 \%)$ (Gambar 2). Hal ini sesuai dengan penelitian oleh $\mathrm{Ng}$, Acker (2018) bahwa terdapat perbedaan perilaku dalam persiapan bepergian berdasarkan jenis kelamin, yaitu perempuan lebih teliti dalam mempersiapkan perjalanan daripada lakilaki. Sedangkan pada Tabel 2 dapat dilihat mayoritas tempat yang dituju adalah Jawa Timur dengan lama perjalanan 1 hingga 6 jam. Lamanya perjalanan dapat mempengaruhi persiapan obat yang akan dibawa terkait gangguan kesehatan selama perjalanan.

Tabel 3 menggambarkan lama persiapan pada berbagai kelompok umur, umumnya hanya membutuhkan lama persiapan kurang dari 2 minggu (96\%) untuk melakukan perjalanan ke luar kota. Berbeda dengan penelitian yang dilakukan di terminal keberangkatan Bandara Internasional Kairo, Mesir dengan 1500 responden, menunjukkan $5,7 \%$ responden mempersiapkan perjalanannya tidak lebih dari 2 minggu, $5,4 \%$ selama 3 minggu, $38,6 \%$ selama 1 bulan, dan $50,3 \%$ selama lebih dari 1 bulan (El-Ghitany et al., 2018). Perbedaan lamanya persiapan yang dilakukan untuk melakukan perjalanan ini disebabkan oleh perbedaan tujuan dari tiap wisatawan. Semakin jauh tujuan perjalanan, maka persiapan yang dibutuhkan semakin lama.

Tabel 1. Data Demografi

\begin{tabular}{lc}
\hline \hline Karakteristik (n=150) & $\mathrm{n}(\%)$ \\
\hline Jenis Kelamin & \\
\hline Laki-laki & $89(59,3)$ \\
Perempuan & $61(40,7)$ \\
\hline Umur & \\
\hline$<17$ tahun & $1(0,7)$ \\
$17-25$ tahun & $80(53,3)$ \\
$26-35$ tahun & $30(20)$ \\
$36-45$ tahun & $22(14,7)$ \\
$46-55$ tahun & $12(8)$ \\
$56-65$ tahun & $5(3,3)$ \\
\hline Status Pernikahan & \\
\hline Menikah & $69(46)$ \\
Belum Menikah & $81(54)$ \\
\hline Pendidikan Terakhir & \\
\hline SD/Sederajat & $6(4)$ \\
SMP/Sederajat & $13(8,7)$ \\
SMA/Sederajat & $77(51,3)$ \\
Diploma (DI, DII, DIII) & $16(10,7)$ \\
Sarjana (DIV, S1, S2, S3) & $38(25,3)$ \\
\hline Status Pekerjaan & \\
\hline Bekerja & $98(65,3)$ \\
Tidak Bekerja & $13(8,7)$ \\
Pelajar/Mahasiswa & $36(24)$ \\
Lain - lain & $3(2)$ \\
\hline Jenis Pekerjaan & \\
\hline PNS/Pegawai & $12(8)$ \\
BUMN/ABRI & \\
Pegawai Swasta & $63(42)$ \\
Wiraswasta & $21(14)$ \\
Ibu Rumah Tangga & \\
\hline \hline
\end{tabular}

Salah satu persiapan sebelum bepergian adalah mencari informasi terkait tempat tujuan. Penelitian sebelumnya menyatakan bahwa informasi yang umum dicari adalah informasi kesehatan, cuaca, gaya hidup, akomodasi, transportasi, tingkat kejahatan, status wilayah, dan tempat wisata (Kalanlar et al., 2018). Berdasarkan hasil penelitian ini, diperoleh jenis informasi terbanyak yang dicari oleh responden terkait tempat tujuan adalah transportasi (83,5\%). Informasi terkait transportasi umumnya dilakukan untuk memastikan lancarnya perjalanan, seperti jenis dan biaya transportasi (Nelson, 2018). Akan tetapi, hanya $27,3 \%$ responden yang mencari informasi tentang kesehatan sebelum bepergian karena responden merasa telah memiliki persiapan yang cukup $(53,2 \%)$. 
Tabel 2. Karakteristik Perjalanan

\begin{tabular}{lc}
\hline \hline Karakteristik $(\mathrm{n}=150)$ & $\mathrm{n}(\%)$ \\
\hline Tempat tujuan & $118(78,6)$ \\
\hline Jawa Timur & $21(14)$ \\
Jawa Tengah & $4(2,7)$ \\
D.K.I Jakarta & $3(2)$ \\
D.I. Yogyakarta & $3(2)$ \\
Bali & $1(0,7)$ \\
Kalimantan Timur & \\
\hline Jumlah tujuan & $138(92)$ \\
\hline 1 (satu) & $8(5,3)$ \\
2 (dua) & $4(2,7)$ \\
\hline 2 (lebih dari dua) & \\
\hline Alasan bepergian & $12(8)$ \\
\hline Belajar & $63(42)$ \\
Berlibur & $21(14)$ \\
Bekerja & $9(6)$ \\
Mengunjungi Teman/keluarga & \\
Lain-lain & $45(30)$ \\
\hline Jumlah anggota bepergian & \\
\hline Sendiri & $64(42,7)$ \\
1 (satu) & $27(18)$ \\
2 (dua) atau lebih & $59(39,3)$ \\
\hline Lama perjalanan & \\
\hline 1-6 jam & $115(76,7)$ \\
$7-12$ jam & $32(21,3)$ \\
13-18 jam & $2(1,3)$ \\
>18 jam & $1(0,7)$ \\
\hline Lama tinggal & $104(69,3)$ \\
\hline <1 bulan & $10(6,7)$ \\
1-3 bulan 3 bulan & $36(24)$ \\
\hline \hline
\end{tabular}

Tabel 3. Persiapan Perjalanan

\begin{tabular}{lc}
\hline \hline Karakteristik $(\mathrm{n}=150)$ & $\mathrm{n}(\%)$ \\
\hline Lama persiapan & \\
\hline < 2 minggu & $144(96)$ \\
$3-4$ minggu & $2(1,3)$ \\
$>1$ bulan & $4(2,6)$ \\
\hline Percarian informasi tempat tujuan & \\
\hline Ya & $85(56,7)$ \\
Tidak & $65(43,3)$ \\
\hline Pencarian informasi terkait & \\
kesehatan & \\
\hline Ya & $41(27,3)$ \\
Tidak & $109(72,3)$ \\
\hline \hline
\end{tabular}

Apoteker memiliki peran penting sebagai salah satu tenaga kesehatan dalam menyediakan pelayanan kesehatan untuk perjalanan. Peran apoteker di Amerika Serikat telah terbagi menjadi lima yaitu pemberian konseling terkait kesehatan pretravel, pemberian vaksin, pemberian obat dengan resep, menyediakan obat-obatan pribadi dan keperluan lain yang dibutuhkan pasien untuk perjalanannya (Hurley-Kim et al., 2018). Seperti halnya peran apoteker di Amerika Serikat, apoteker di Kanada berperan dalam konsultasi terkait obatobatan pribadi yang akan dibawa ketika perjalanan dan penyiapan obat dengan resep dikarenakan pasien membutuhkan obat lebih banyak (Houle, 2018). Namun pada penelitian ini, hanya $2,8 \%$ responden yang menjadikan apoteker sebagai sumber informasi terkait kesehatan (Tabel 5).

Tabel 4. Pengetahuan Kesehatan

\begin{tabular}{lc}
\hline \hline Karakteristik $(\mathrm{n}=150)$ & $\mathrm{n}(\%)$ \\
\hline Pembawaan Obat Pribadi & \\
\hline Ya & $70(46,7)$ \\
Tidak & $80(53,3)$ \\
\hline Cara Penyimpanan Obat & \\
\hline Langsung dalam tas & $69(81,2)$ \\
Tas khusus obat & $16(18,8)$ \\
\hline \hline
\end{tabular}

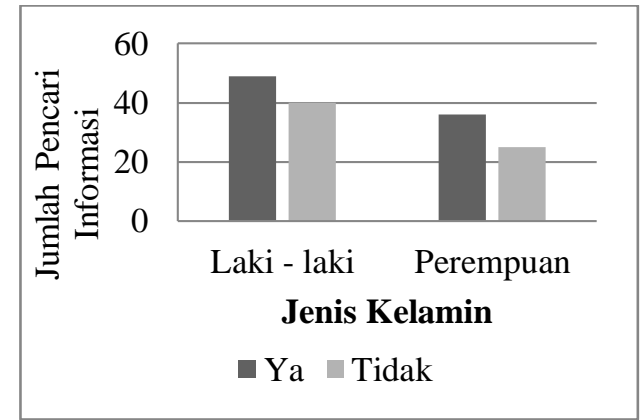

Gambar 2. Hubungan Jenis Kelamin dengan Perilaku dalam Persiapan Bepergian

Untuk mengetahui persiapan masyarakat tentang kesehatan sebelum bepergian, kami mengajukan pertanyaan mengenai obat-obatan yang biasa dibawa selama bepergian. Hasil survei menunjukkan sebanyak 70 responden membawa obatobatan pribadi dan $81,2 \%$ diantaranya menyimpan obat-obatan langsung dalam tas jinjing (Tabel 4). Hal ini sesuai dengan penelitian Zwar (2018) yang menyatakan bahwa wisatawan sebaiknya menyimpan obat-obatan dalam tas jinjing dan tetap di dalam kemasan aslinya untuk memudahkan pencarian obat ketika dibutuhkan selama perjalanan. Pada penelitian ini, obat-obatan pribadi yang dibawa seperti obat antimual, obat sakit kepala, obat diare, obat maag, obat antialergi, P3K, lotion antinyamuk, sunscreen, vitamin, minyak kayu putih, dan obat lain meliputi CTM ( $\mathrm{n}=1)$; obat flu dan parasetamol $\quad(n=1) ; \quad$ Freshcare $\AA \quad(n=1)$; Minyak Tawon ${ }^{\circledR} \quad(\mathrm{n}=1)$; obat asma $(\mathrm{n}=1)$; obat kolesterol $(\mathrm{n}=1)$; dan Tolak Angin ${ }^{\circledR}$ $(n=3)$ (Tabel 6). 
Tabel 5. Jawaban Responden Terkait Pencarian Informasi Tentang Perjalanan

\begin{tabular}{|c|c|c|}
\hline Kriteria & Jenis & $\mathrm{n}(\%)$ \\
\hline \multirow{6}{*}{$\begin{array}{l}\text { Jenis } \\
\text { Informasi } \\
(n=85)\end{array}$} & Transportasi & $71(83,5)$ \\
\hline & Akomodasi & $27(31,8)$ \\
\hline & Cuaca & $20(23,5)$ \\
\hline & Kesehatan & $9(10,6)$ \\
\hline & Tingkat Kejahatan & $7(8,2)$ \\
\hline & Lain - Lain & $3(3,5)$ \\
\hline \multirow{5}{*}{$\begin{array}{l}\text { Alasan } \\
\text { Tidak } \\
\text { Mencari } \\
\text { Informasi } \\
\text { Terkait } \\
\text { Kesehatan } \\
(\mathrm{n}=109)\end{array}$} & $\begin{array}{l}\text { Memiliki } \\
\text { persiapan yang } \\
\text { cukup }\end{array}$ & $58(53,2)$ \\
\hline & $\begin{array}{l}\text { Tidak berisiko } \\
\text { terkena penyakit } \\
\text { di tempat } \\
\text { perjalanan }\end{array}$ & $29(26,6)$ \\
\hline & Sibuk & $18(16,5)$ \\
\hline & Alasan Lain & $7(6,4)$ \\
\hline & $\begin{array}{l}\text { Tidak mengetahui } \\
\text { jenis penyakit } \\
\text { selama perjalanan }\end{array}$ & $5(4,8)$ \\
\hline \multirow{7}{*}{$\begin{array}{l}\text { Sumber } \\
\text { Informasi } \\
(n=144)\end{array}$} & Teman & $50(34,7)$ \\
\hline & Internet & $39(27,1)$ \\
\hline & Keluarga & $35(24,3)$ \\
\hline & Dokter & $11(7,6)$ \\
\hline & Apoteker & $4(2,8)$ \\
\hline & Majalah/Brosur & $3(2,1)$ \\
\hline & Agensi Travel & $2(1,4)$ \\
\hline
\end{tabular}

Kelebihan dari penelitian ini adalah memberikan profil persiapan dari masyarakat sebelum bepergian sehingga bisa mempersiapkan kebutuhan, khususnya kesehatan serta belum adanya penelitian serupa terkait pengambilan data di terminal bus, yang diharapkan dapat menjadi acuan bagi penelitian lain. Adapun kelemahan dari penelitian ini adalah informasi yang didapatkan belum komprehensif, misalnya jika terdapat masyarakat yang akan pergi ke luar kota untuk bekerja secara pulang-pergi, tentu akan berbeda dengan persiapan masyarakat yang akan pergi ke luar kota untuk berlibur dengan jarak dan lama di tempat tujuan yang sama.

Pada penelitian ini dapat diketehui bahwa masyarakat yang bepergian dari Terminal Bungurasih umumnya belum mencari informasi terkait pre-travel health preparation melalui apoteker dan belum mengetahui cara penyimpanan obat dengan benar selama perjalanan. Oleh karena itu, dibutuhkan peran tenaga kesehatan khususnya apoteker untuk mengedukasi masyarakat mengenai pentingnya pre-travel health preparation.
Tabel 6. Jenis Obat yang Dibawa dan Gangguan Kesehatan dalam Perjalanan dari Responden

\begin{tabular}{|c|c|c|}
\hline & Jenis & $\mathrm{n}(\%)$ \\
\hline \multirow{11}{*}{$\begin{array}{l}\text { Jenis Obat } \\
\text { yang } \\
\text { Dibawa } \\
(\mathrm{n}=70)\end{array}$} & $\begin{array}{l}\text { Minyak Kayu } \\
\text { Putih }\end{array}$ & $39(55,7)$ \\
\hline & Obat Antimual & $26(37,1)$ \\
\hline & Vitamin & $23(32,8)$ \\
\hline & $\begin{array}{l}\text { Obat Sakit } \\
\text { Kepala }\end{array}$ & $20(28,6)$ \\
\hline & Obat Maag & $13(18,6)$ \\
\hline & Lain - Lain & $9(12,8)$ \\
\hline & $\begin{array}{l}\text { Lotion Anti- } \\
\text { nyamuk }\end{array}$ & $7(10,0)$ \\
\hline & Obat Diare & $5(7,1)$ \\
\hline & Obat Antialergi & $5(7,1)$ \\
\hline & P3K & $4(5,7)$ \\
\hline & Sunscreen & $3(4,3)$ \\
\hline Gangguan & Pusing & $46(42,2)$ \\
\hline Kesehatan & Mual & $40(36,7)$ \\
\hline Selama & Muntah & $12(11,0)$ \\
\hline $\begin{array}{l}\text { Perjalanan } \\
(\mathrm{n}=109)\end{array}$ & Lain - Lain & $11(10,1)$ \\
\hline
\end{tabular}

\section{KESIMPULAN}

Pada penelitian ini dapat disimpulkan bahwa masyarakat yang bepergian dari Terminal Bungurasih umumnya belum mencari informasi terkait pre-travel health preparation melalui apoteker dan belum mengetahui cara penyimpanan obat dengan benar selama perjalanan. Oleh karena itu, dibutuhkannya peran tenaga kesehatan khususnya apoteker untuk mengedukasi masyarakat mengenai pentingnya pre-travel health preparation.

\section{UCAPAN TERIMA KASIH}

Terima kasih kepada Bu apt. Elida Zairina, S.Si., M.P.H., Ph.D. selaku pembimbing dan penanggungjawab mata ajar kuliah farmasi masyarakat serta kepada $\mathrm{Bu}$ apt. Gesnita Nugraheni, S.Farm., M.Sc. selaku koordinator praktikum farmasi masyarakat Fakultas Farmasi Universitas Airlangga.

\section{DAFTAR PUSTAKA}

Adou, A.A., Napolitano, F., Vastola, A., Angelillo, I.F., 2019. Travelers' knowledge, attitudes, and behavior related to infectious diseases in Italy, PLoS ONE, 14(4), p 1-12 
Becken, S. 2014. The Importance of Climate and Literature Review. Diakses pada tanggal 24 Oktober 2019 , https://www.researchgate.net/publication/4792 9582_The_importance_of_climate_and_weath er_for_tourism_literature_review/link/00b7d5 34471be47b8a000000/download

Chalidi, Z. 2017. Analisis Tingkat Pemahaman Masyarakat Kota Medan terhadap Lembaga Keuangan Mikro Syariah

Direktorat Bina Penggunaan Obat Rasional. 2008. Modul I Materi Pelatihan Peningkatan Pengetahuan dan Keterampilan Memilih Obat bagi Tenaga Kesehatan. Jakarta

El-Ghitany, E.M., Abdelmohsen, M., Farghaly, A.G., El-Gawwad, E.A., El-Wahab, E.W.A., 2018. Travel Health Survey: Risk Perception, Health-Seeking Behavior, and Subjective Evaluation of Travel Health Services in Egypt, International Journal of Travel Medicine and Global Health, 6(1), p 16-24

Houle, S. 2018. Pharmacy travel health services: current perspectives and future prospects, Integrated Pharmacy Research and Practice, Volume 7, p 13-20

Hurley-Kim, K., Goad, J., Seed, S., Hess, K.H., 2018. Pharmacy-Based Travel Health Services in the United States, Pharmacy, 7(1), p. 5

Kalanlar, B., Senel, M., Gürse, E.T., Gönül, N., Bilgiç, B., Aydoğan, F.K., Kan, O., 2018. International Travelers' Behaviors and Knowledge of Travel Health, Travel-Related Diseases, and Vaccinations: A Cross-Sectional Study, International Journal of Travel Medicine and Global Health, 6(4), p 168-173

Kamata, K., Birrer, R.B. and Tokuda, Y., 2017. Travel medicine: Part 1-The basics, Journal of General and
Medicine, 18(2), p 52-55

Lisowska, A. 2017. Crime in Tourism Destinations: Research Review, Tourism 2017, 27/1, p 31-39

Mulley, C., Clifton, G.T., Balbontin, C., Ma, L., 2017. Information for travelling: awareness and usage of the various sources information available to public transport users in NSW. Transportation Research Part A: Policy and Practice, 101, p 111-132

Nelson, J.D. 2018. Perfect information and ITS. In: Ison, S., Cowie, J. (Eds). The Routledge handbook of transport economics. Routledge, Abingdon, p 62-73

Ng, W., Acker, A, 2018. Understanding Urban Travel Behaviour by Gender for Efficient and Equitable Transport Policies, International Transport Forum, (2018-01), p. 19

Poksiri, R., Phumratanaprapin, W., Poovorawan, K., Chotivanich, K., Punrin, S., Piyaphanee, W., 2018. Knowledge, attitudes, practices, and self-treatment of sick international travelers regarding communicable and noncommunicable diseases, Journal International Tropical Medicine, 7, p 14-19.

Turkish Statistical Institute. 2017. Turism Statistics, 2017.

WHO. 2010. Health Risks and Precautions: General Considerations. Diakses pada tanggal $24 \quad$ Oktober 2019, https://www.who.int/ith/ITH2010chapter1.pdf

Zwar, N. 2018. Travelling with medicines in 2018, Australian Prescriber, 41(4), p 102104. 